\title{
Electric motor-glider powered by a hydrogen fuel cell stack
}

In alphabetical order:

Piotr Czarnocki ${ }^{1 *}$, Magdalena Dudek ${ }^{2}$, Krzysztof Drabarek ${ }^{1}$, Wojciech Frączek ${ }^{1}$, Grzegorz Iwański ${ }^{4}$, Tomasz Miazga ${ }^{4}$, Marcin Nikoniuk ${ }^{5}$ Andrzej Raźniak ${ }^{2}$ and Maciej Rosół ${ }^{3}$

${ }^{1}$ Institute of Aviation and Applied Mechanics, Warsaw University of Technology, Nowowiejska 24, 00-665 Warsaw, Poland

${ }^{2}$ AGH University of Science and Technology, Faculty of Energy and Fuels, Al. Mickiewicza 30, 30059 Krakow, Poland

${ }^{3}$ AGH University of Science and Technology, Faculty of Electrical Engineering, Automatics, Computer Science and Biomedical Engineering, Al. Mickiewicza 30, 30-059 Krakow, Poland

${ }^{4}$ Institute of Control and Industrial Electronics, Warsaw University of Technology, Koszykowa 75, 00-662 Warsaw, Poland

${ }^{5}$ Faculty of Transport, Warsaw University of Technology, Koszykowa 75, 00-662 Warsaw, Poland

\begin{abstract}
The paper presents the current development of the AOS-H2 electric motor-glider project. The project encompasses the design and manufacture of an electric propulsion system (EPS) and a CF/epoxy airframe to be used as a flying test platform for the designed EPS. A 40$\mathrm{kW}$ electric motor is supplied by a 10-kW PEM fuel cell stack and a Li-ion battery during run-up and ascent and by the fuel cell stack alone during steady flight. The airframe and the EPS have been completed; the results of bench tests of the EPS have proved that it meets the established requirements..
\end{abstract}

\section{Introduction}

The paper presents the current development of the project concerning the AOS- $\mathrm{H}_{2}$ electric motor-glider equipped with a proton exchange membrane (PEM) fuel cell stack. The AOS- $\mathrm{H}_{2}$ project was undertaken to gain experience in the field of possible application of PEM fuel cells for small aviation, as well as to provide students with an opportunity for further development of the project, and design and completion of the related ground and flight tests. Information about a few similar projects could be found in available literature [1-4], though unfortunately, the available publications lack vital details.

The 1.5 million Euro total budget of the project covers the design and manufacturing of an electric propulsion system (EPS) and a CF/epoxy airframe, Fig. 1, which is going to serve the purpose of a flying test platform. The project participants are: Rzeszów University of Technology (Leader), AGH University of Science and Technology (responsible for the

*Corresponding author: pecz@meil.pw.edu.pl 
PEM cell stack technology), Warsaw University of Technology (responsible for the airframe, energy management system and electric propulsion system designs, excluding the PEM cell stack) and Glider Factory JEŻÓW (responsible for the airframe manufacturing). The project is in progress and will end in December 2019.

The considered EPS, Fig. 2, included an electric $40 \mathrm{~kW}$ motor from ENSTROJ, two modules $5 \mathrm{~kW}$ PEM fuel cell connected electrically in series give 10kW PEM fuel cell stack, a Li-Ion battery set consisting of 96 Li-Ion KOKAM cells, and DC/DC and DC/AC converters. Two 12 liter composite tanks LC12.0-30A from the HES Energy Systems were designed for the storage of gaseous hydrogen at the maximum pressure of 300 bars. The energy management system (EMS) was worked out to control all the EPS components. The glider is going to be certified as Experimental in accordance with CS22.
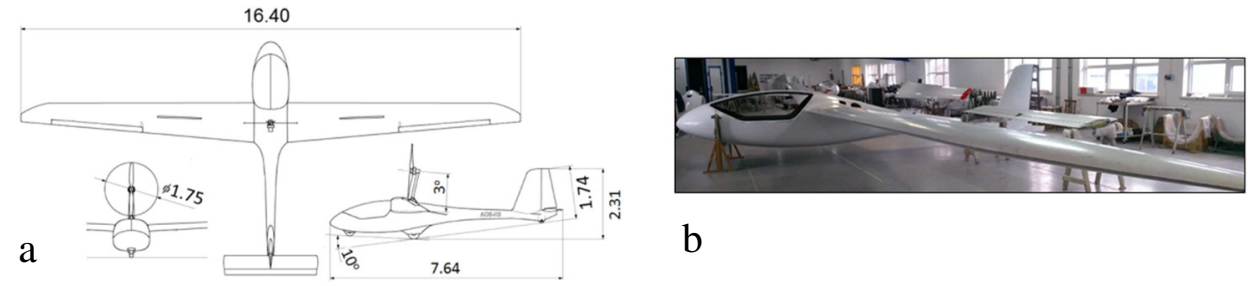

b

Fig. 1. (a) general layout and dimensions, (b) $\mathrm{AOS}-\mathrm{H}_{2}$ airframe, empty weight $=305 \mathrm{~kg}$

\section{$2 \mathrm{AOS}-\mathrm{H}_{2}$ airframe and location of EPS components}

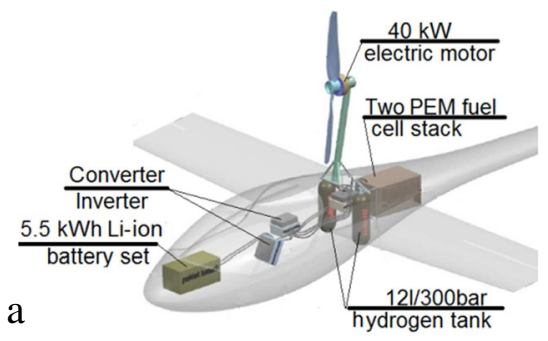

b

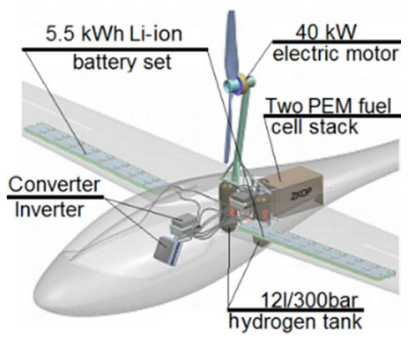

Fig. 2. Considered arrangements of the EPS components.

The AOS- $\mathrm{H}_{2}$ airframe was made of a CF/epoxy composite with the wet lay-up technique to decrease tooling costs. The airframe technical specification is shown in Table1.

Table 1. Airframe specification

\begin{tabular}{|l|c|l|c|}
\hline Max. take-off weight & $660 \mathrm{~kg}$ & Wing area & $15.8 \mathrm{~m}^{2}$ \\
\hline Empty weight (EPS excluded) & $319 \mathrm{~kg}$ & Airfoil & $\mathrm{NN} \mathrm{18-17}$ \\
\hline Payload & $120 \mathrm{~kg}$ & Aspect ratio & 17 \\
\hline Wing span & $16.4 \mathrm{~m}$ & Max. gliding ratio & 31 (clean configuration) \\
\hline
\end{tabular}

Several variants of the EPS component arrangements were analysed taking into consideration several design problems, e.g., cooling of the PEM fuel cells and Li-Ion battery stacks, and the DC/DC converter and inverter, ventilation of the PEM fuel cell stack and the hydrogen supply system, and balance. As a result of these considerations, the arrangement variant shown in Fig. 2a was chosen for fabrication. Although the cockpit design offers the possibility for accommodation of two people, the present $\mathrm{AOS}-\mathrm{H}_{2}$ version is going to be one seater. The cockpit could accommodate two people, while the Li-Ion battery cells were located inside the wings (Fig. 2b). However, for the time being, such a design would result in an overrun of the maximum weight limitation, but an increase in gravimetric power density of EPS components is likely in the near future [5], especially in 
the case of PEM fuel cells and such a design would meet the maximum weight limit. Bearing in mind the above, an additional set of wings that could accommodate a Li-Ion battery set was built outside of the AOS- $\mathrm{H}_{2}$ project.

To provide the necessary space to accommodate the PEM fuel cell stack, a metal mast with the electric motor mounted on its top was permanently fixed outside the fuselage. The concept of cooling of the PEM fuel cell stack and Li-Ion battery cell stacks, and the expected air flows are schematically shown in Fig. 3.
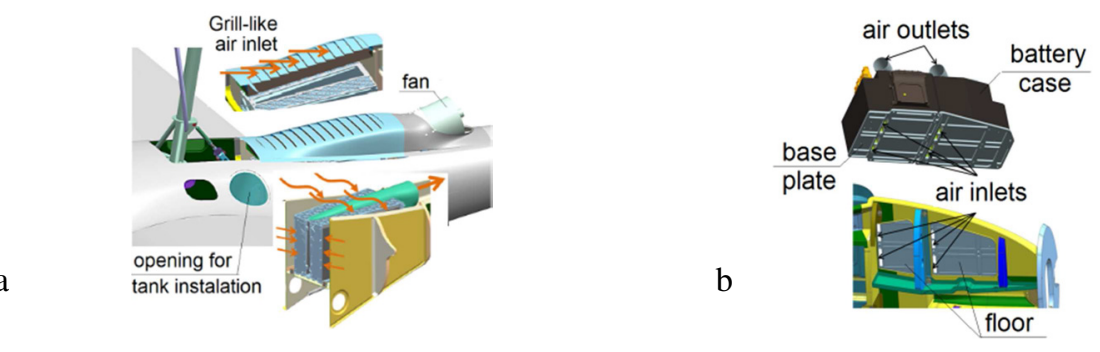

Fig. 3. Air cooling of (a) the PEM stack and (b) the battery set.

\section{Assumed test mission profile and expected performance}

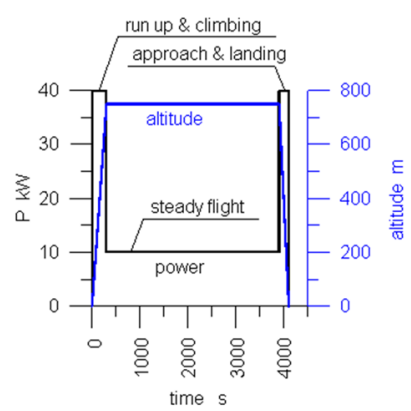

Fig. 4. Mission profile - power demand and flight altitude versus time

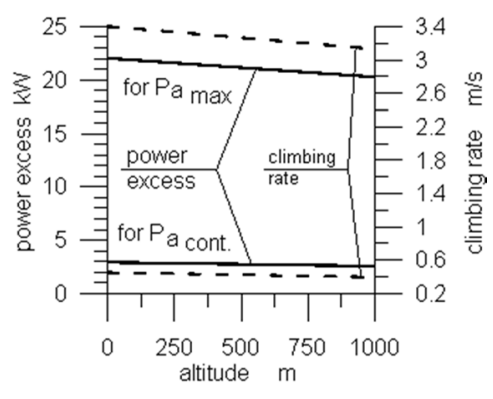

Fig. 5. Climb rates and power excess versus flight altitude for the maximum available power $(40 \mathrm{~kW})$ and continuous power $(10 \mathrm{~kW})$.

The assumed test mission profiles in terms of the power demand vs. time of mission and the altitude vs. time of mission are shown in Fig. 4. The mission covered run-up and 5 minutes climbing (first stage) with the climb rate approximately equal to $3 \mathrm{~m} / \mathrm{s}$, then 1 hour level flight at the altitude of approximately $700 \mathrm{~m}$ (second stage). During the first stage of the flight, the electric motor is going to be driven by the Li-Ion battery and PEM fuel cell stacks offering $40 \mathrm{~kW}$, while during steady flight by the PEM fuel cell stack alone offering $10 \mathrm{~kW}$. The predicted climb rate and the power excess diagrams are shown in Fig. 5.

\section{Hydrogen-oxygen 10 kW PEMFC stack}

A 10-kW PEMFC stack was constructed of two 5-kW modules, A and B, connected in series. The fuel source chosen to supply the stack consisted of gaseous hydrogen compressed to 220-300 bar in an ultra-light composite cylinder. Two LC12.0-30A composite cylinders (Horizon Fuel Cell Technologies, Singapore) with a total capacity of $24 \mathrm{dm} 3$ were installed aboard a motor glider. The previous papers $[6,7]$ presented selected results of electrical and electrochemical investigations of the initial prototype of the $10-\mathrm{kW}$ 
PEMFC, performed in laboratory conditions. Based on the results presented in these papers, auxiliary devices designed and optimised for the cooling system as well as for the PEMFC stack controller were applied as part of the investigated prototype. The voltage (U)-current (I) and power (P)-current (I) dependencies recorded for the 10-kW PEMFC stack are shown in Fig. 6a. It can be seen from the U(I) curve that the open-circuit voltage (OCV) of the stack was $\sim 230$ V DC.

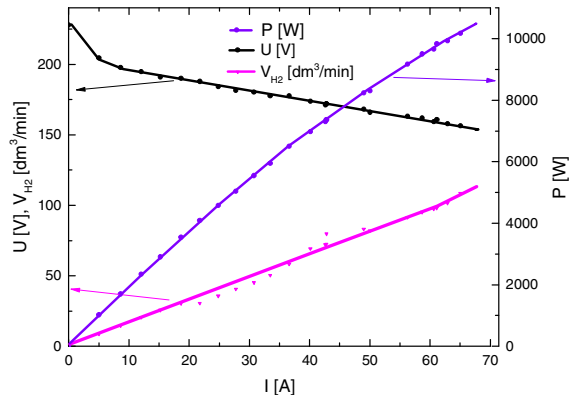

Fig. 6a. The dependence of voltage (U)current (I), power (P) - current (I) and hydrogen fuel consumption $\left(\mathrm{V}_{\mathrm{H} 2}\right)$ - current (I) recorded for the $10 \mathrm{~kW}$ PEMFC

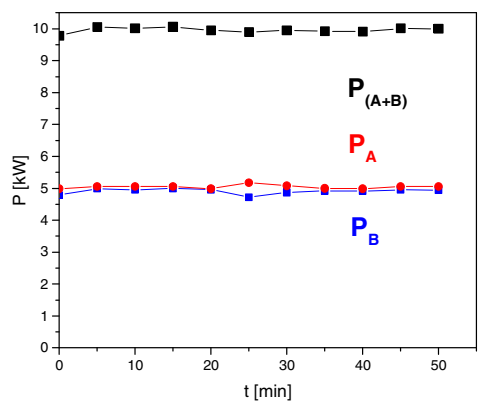

Fig. 6b. Dependence of the nominal power of the PEMFC stack (total power P for A + B stack) and nominal power recorded for $5-\mathrm{kW}$ module $(\mathrm{A})$ or (B) during PEMFC stack operation over time

As the current increased, the voltage decreased linearly to approximately $154 \mathrm{~V}$ at $67 \mathrm{~A}$. The electrical power of the 10-kW PEMFC stack reached more than $10 \mathrm{~kW}$ in these conditions. As the current increased, the power increased linearly without reaching its maximum point. The gaseous hydrogen in the PEMFC stack was supplied in order to produce electrical energy as well as energy for the cleaning and self-humidification requirements of the stack itself. As can be seen, the utilisation of hydrogen fuel (Fig. 6a) for producing electrical power rose along with increases in the electrical current of the stack. In the case of operation of the PEMFC stack at nominal power $(10 \mathrm{~kW})$, the calculated average hydrogen consumption was $\sim 114$ [dm3/min]. In the case of hydrogen compressed under 300 bar in two composite cylinders $(2 \times 12 \mathrm{dm} 3)$, the expected time of operation of the PEMFC stack was about 50 min. Fig. $6 \mathrm{~b}$ presents the correlations between total power $\mathrm{P}$ and time recorded for the PEMFC stack $(\mathrm{A}+\mathrm{B}$ modules) as well as for the $\mathrm{A}$ and $\mathrm{B}$ modules independently over the predicted time of flight.

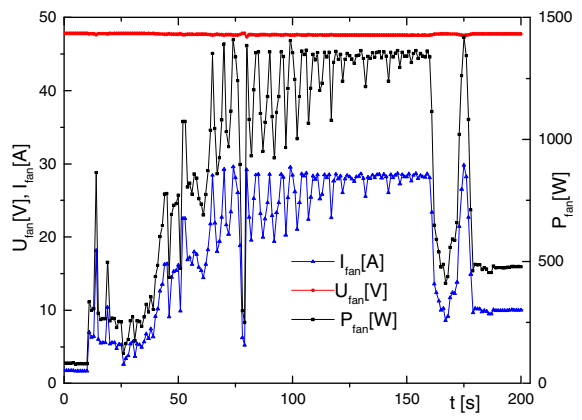

Fig. 7a. Waveforms of current $\left(\mathrm{I}_{\mathrm{fan}}\right)$, voltage $\left(\mathrm{U}_{\text {fan }}\right)$, and power $\left(\mathrm{P}_{\text {fan }}\right)$ taken from the supply source by the speed controller for the cooling fan's electric motor, recorded while the PEMFC stack was operating with a power of $10 \mathrm{~kW}$

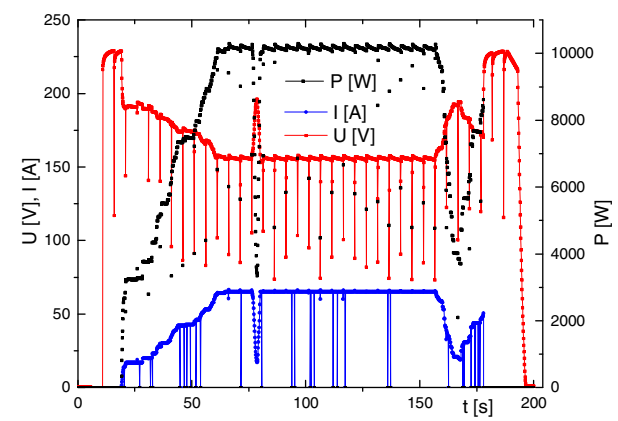

Fig. 7b. Waveforms of current (I), voltage (U), and power (P) for the PEMFC stack recorded while the cooling system was being tested (shown in Fig. 7a) 
(shown in Fig. 7b)

Fig. 7a presents the performance of the air-cooling system recorded during the operation of the 10-kW PEMFC stack under variable electric load (Fig. 7b) when the cooling system was being tested. The main task of the cooling system is the removal of waste heat from the stack during its operation under load. The temperature distribution in individual MEA cells in the PEMFC stack is also a crucial factor in obtaining the required efficiency and durability of the stack during long-term operation. The operating temperature range of the stack was established at between 50 and $65^{\circ} \mathrm{C}$, taking into account the conditions associated with the laminate structure of the motor glider and the properties of the PEMFC membranes. The 2-stage axial cooling fan and speed controllers were supplied with DC voltage of $\mathrm{U}_{\text {fan }}=48 \mathrm{~V}$. The cooling system was monitored by the main stack controller. Current (Ifan) and power $\left(\mathrm{P}_{\mathrm{fan}}\right)$ consumption depended on the main fuel cell controller, which maintained the optimum temperature of the fuel cell stack between 50 and $65^{\circ} \mathrm{C}$. During the analysed tests (Fig. 7a, b) we observed the PEMFC turn on the cooling system and initiate the operation required to supply power of $250 \mathrm{~W}$. The increase in electrical power up to $10 \mathrm{~kW}$ around the 60th second of operation caused an increase in the electric power needed to supply the cooling system to $1400 \mathrm{~W}$. When turning off the PEMFC stack around the 180th second, the controller switched the fan to maximum speed in order to cool the device to a safe temperature below $40{ }^{\circ} \mathrm{C}$, so that the cooling system could then be turned off.

The PEMFC stack was built from single fuel cells using a perfluorosulfonic acid ionexchange (PFSA) membrane. The electrical internal resistance of membrane electrode assemblies (MEA) of this kind is very sensitive to the humidity level of the polymer electrolyte, and is necessary in order to ensure a cycling self-humidification process. This problem is particularly important in the construction of an air-cooled open-cathode PEMFC stack. The humidification process can be implemented via a short circuit unit (SCU system). The basic advantages of SCU humidification include the even distribution of a specific portion of water to all individual PEMFCs constituting the fuel cell stack. The effect of this positive action is not only improvement of electrical parameters by approximately $15-20 \%$ as a result of achieving optimal humidity in the Nafion-based membranes, but also extension of the lifetimes of these membranes [8, 9]. In the prototype 10-kW PEMFC stack, the humidification process could be implemented via SCU in either of two ways: in the first option, the SCU unit in each 5-kW module operated at the same time for e.g. a period of $10 \mathrm{~s}$; in the second option, the SCU unit performance in each module (A or B) was capable of independent operation every $5 \mathrm{~s}$..

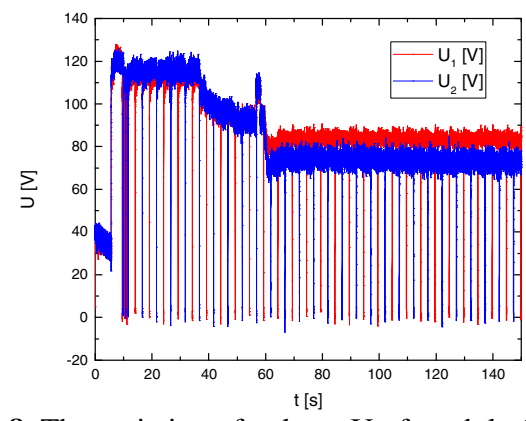

Fig. 8. The variation of voltage U of module (A) or (B) (measured separately in both stacks) vs. time.

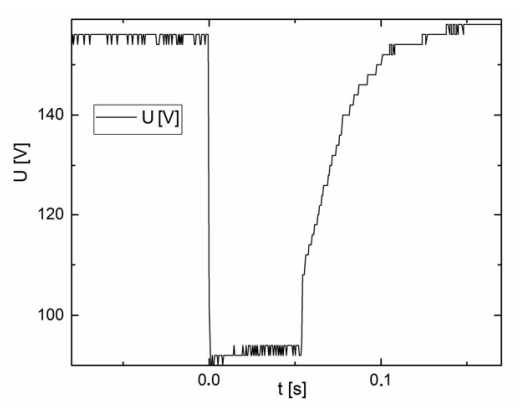

Fig. 9. Registered waveforms of fuel cell voltage $\mathrm{U}_{\mathrm{FC}}$ during SCU system operation.

Fig. 8 presents the variation in the voltage (U) of module A or B (measured separately) vs time. As can be seen in this graph, the operating time for the SCU is divided into 
intervals of 5 s. Fig. 9 presents an example of SCU performance in the 10-kW PEMFC stack (under an electrical load of $61 \mathrm{~A}$ ) aimed at demonstrating its positive impact on the stack. The voltage output of the 10-kW PEMFC stack under an electrical load of $61 \mathrm{~A}$ was recorded as $154 \mathrm{~V}$; after turning on the SCU system, the voltage increased to $160 \mathrm{~V}$.

\section{Power Electronic Conversion System}

The electric system consists of energy sources which are fuel cell with its own electronic controller, a Li-Ion battery with its own battery management system BMS, a DC/DC converter for fuel cell, a DC/AC converter for the electric motor driving a propeller. A general scheme of the whole electric system is shown in Fig. 10.

Reference fuel cell current $i_{F C}{ }^{\text {ref }}$, controlled by the DC/DC converter, is set constant, but its value can be modified externally, e.g., reduced when the battery current is negative (if battery charging during flight is not recommended) or reduced when the fuel cell voltage drops below some level to avoid fuel cell system overload. Control of the electric motor is made by DC/AC converter and consists of rotational speed outer controller Rn, and motor current inner controller RI responsible for proper torque control and for avoidance of motor current limit exceeding. Reference speed is commanded by the speed command lever via a CAN bus. A second CAN bus is used for information interchange between power electronic converters, battery and on-board computer. The third CAN bus is used for connection of the fuel cell controller, some sensors monitoring fuel cell operation, and an on-board computer.

Among technologies of power transistors used in automotive applications an insulated gate bipolar transistors IGBT, as mature technology [10], are mostly used for the design of tens-kW power inverters. $10 \mathrm{kHz}$ of switching frequency is enough to obtain high quality, sinusoidal motor current with low amount of switching frequency harmonics. At this switching frequency, inverter efficiency equals $97.6 \%$ for full load power $(40 \mathrm{~kW})$.

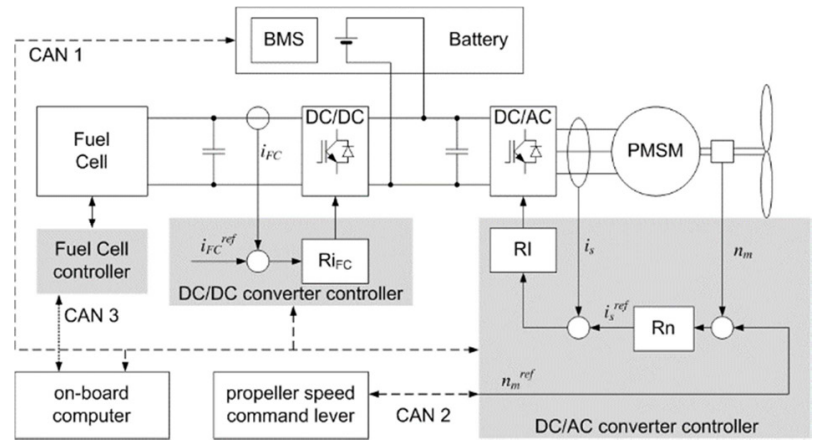

Fig. 10. General scheme of the power electronic conversion unit and its control system.

A new type of semiconductor devices (Silicon Carbide - SiC) provides lower power losses than IGBTs. Especially, switching losses are significantly reduced, which causes that this type of power transistors are nowadays often and often used for high frequency power converters equipped with passive filters. Switching frequency for this type of modules can be higher than $100 \mathrm{kHz}$. Increased switching frequency provides reduction of passive filters components weight and volume, and simultaneously does not significantly increase total power losses [11].

Fig. 11 presents real DC/AC and DC/DC converters designed specially for the described purpose, whereas Tab. 2 and Tab. 3 present selected parameters of the designed converters. Fig. 12 presents the results (waveforms of voltages and currents registered by a scope recorder) of the realized testing profile in stationary conditions. During the whole profile, the Fuel Cell current is constant, whereas battery current flows only during run-up, 
climbing, and maneuvering at the end of the profile. The fuel cell voltage contains voltage drops resulting in Short Circuit Unit operation.

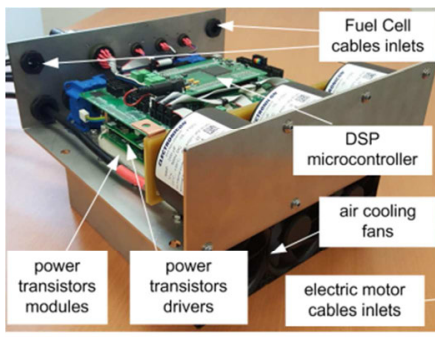

(a)

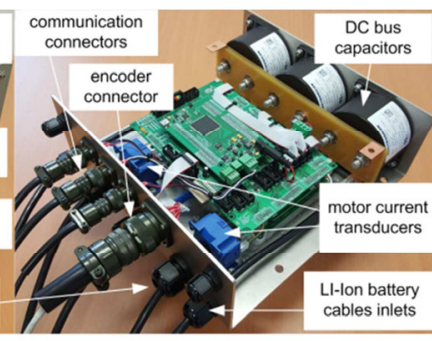

(b)

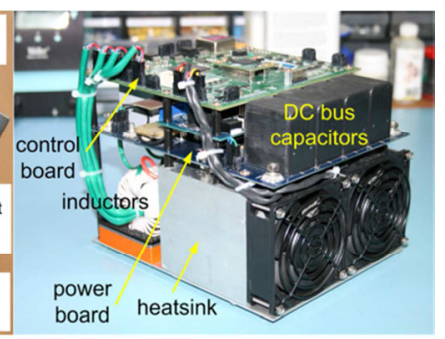

(c)

Fig. 11. View of the power converters (a)(b) motor feeding inverter, (c) fuel cell DC/DC converter.

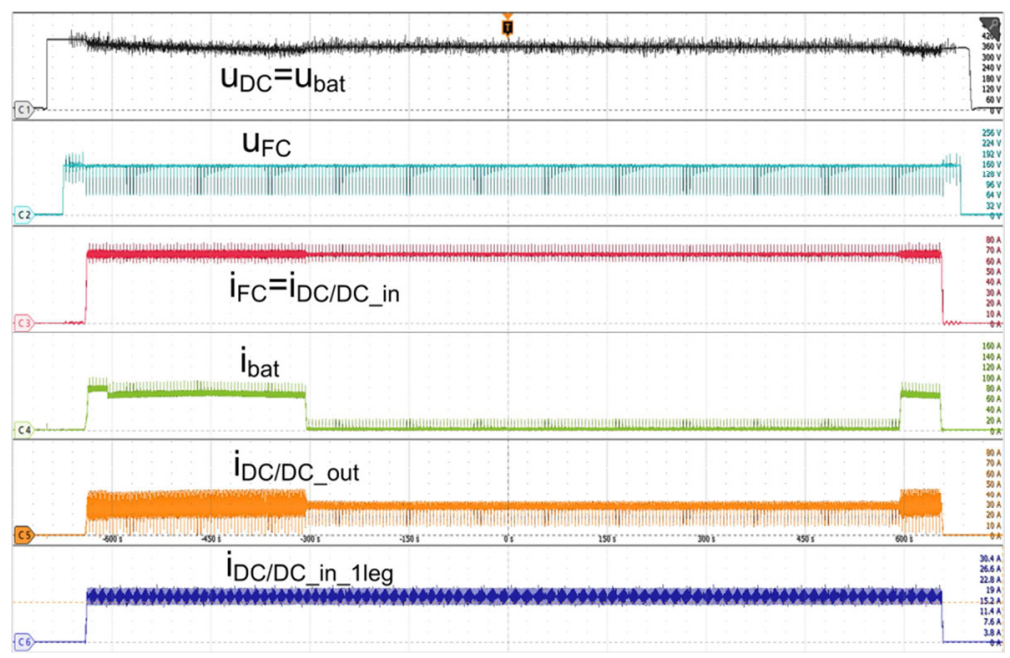

Fig. 12. Waveforms of battery voltage $u_{\text {bat }}$, fuel cell voltage $U_{\mathrm{FC}}$, fuel cell current $\mathrm{i}_{\mathrm{FC}}$, battery current

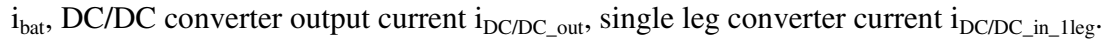

Table 2. Parameters of the DC/AC power converter for motor supply

\begin{tabular}{|c|c|c|c|}
\hline Max DC bus voltage & $450 \mathrm{~V}$ & AC rms rated current & $160 \mathrm{~A}$ \\
\hline AC rms peak current & $320 \mathrm{~A}$ & Rated power & $40 \mathrm{~kW}$ \\
\hline Switching frequency & $10 \mathrm{kHz}$ & Weight & $13 \mathrm{~kg}$ \\
\hline
\end{tabular}

Table 3. Parameters of the DC/DC power converter for PEM fuel cell

\begin{tabular}{|c|c|c|c|}
\hline Max. input current & $100 \mathrm{~A}$ & Rated power & $12 \mathrm{~kW}$ \\
\hline Input voltage range & $0-$ Uout & Switching frequency & $100 \mathrm{kHz}$ \\
\hline Max output voltage & $450 \mathrm{~V}$ & Weight & $4 \mathrm{~kg}$ \\
\hline
\end{tabular}
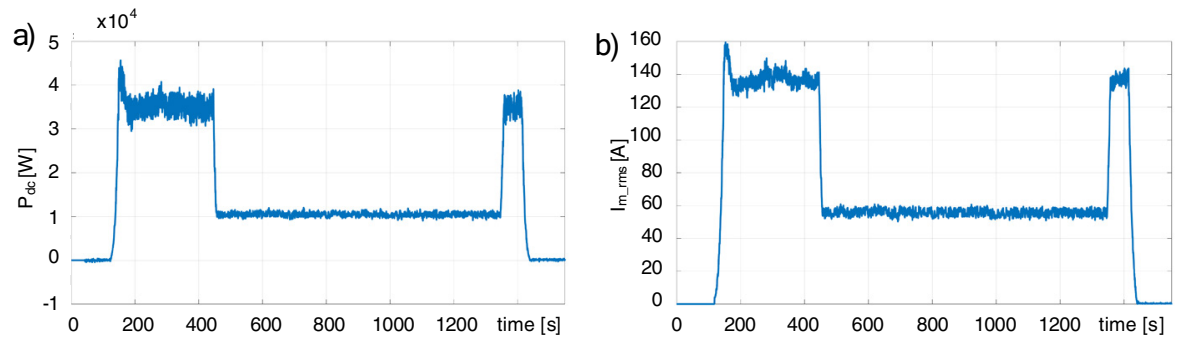
Fig. 13. Waveforms of dc side consumed power $P_{d c}$ (a), and motor rms phase current $I_{m \_r m s}$ (b).

Additional data such as total power consumed on the DC side $\mathrm{P}_{\mathrm{dc}}$ by a power inverter feeding an electric motor has been calculated using power converters embedded measurements. Similarly, the motor rms current has been calculated based on the instantaneous motor current measurement. Both calculated variables are shown in Fig. 13.

\section{Conclusion}

The AOS-H2 airframe was completed and is currently ready for installation of the EPS components. In accordance with expectations, the airframe's empty weight does not exceed $319 \mathrm{~kg}$.

A 10-kW PEMFC stack with an air cooling system was applied as a part of a hybrid power system. The electrical power of the stack reached more than $10 \mathrm{~kW}$. The stack is able to operate continuously with the desired electrical power of $10 \mathrm{~kW}$. The expected time of operation with $10-\mathrm{kW}$ power was estimated at $50 \mathrm{~min}$ for a stack supplied by hydrogen compressed at 300 bar in a composite tank.

Power electronic conversion systems, such as DC/DC converters for fuel cells and DC/AC converters for electric motors, were designed according to the requirements resulting from the power demands and electric parameters, such as nominal current and nominal voltage, of the components. The results of hybrid system operation presented here confirm that the assumed mission can be implemented through delivery of the required power and energy from source of stored energy to an electric motor driving a propeller.

The work was financially supported by The National Centre for Research and Development within the project no. PBS3/A6/24/2015. Some of the measurements were performed using the research infrastructure of the AGH Centre of Energy.

\section{References}

1. https://www.dlr.de/dlr/en/desktopdefault.aspx/tabid-10081/151_read19469/\#/gallery/24480 [accessed in Sept. 2019]

2. G. Romeo, F. Borello, G. Correa, E. Cestino, Jnt. J Hydrogen Energy 38, 1 (2013)

3. T.H. Bradley, A.Moffitt, D.N. Mavris, D.E. Pavekh, J Power Sources, 171, 793 (2007)

4. N. Lapena, J. Mosquera, E. Batller, F. Orti, Journal of Aircraft, 47, 1825 (2010)

5. T. Kadyk, Ch. Winnefeld, R. Hanke-Rauschenbach, U. Krever, Energies, 11, 375, (2018)

6. M. Dudek, A. Raźniak, P. Dudek, M. Korkosz, P. Wygonik, P. Bogusz, W. Fraczek, IOP Conference Series: Earth and Environmental Science, 214, 1 (2019)

7. P. Bogusz, M. Korkosz, P. Wygonik, M. Dudek, A. Raźniak, B. Lis, Maszyny Elektryczne, Zeszyty Problemowe, 115, 55, (2017)

8. Y. Zhana,Y.Guob, J.Zhub,L.Lia, Journal of Power Sources 270, 183, (2014)

9. J. Kim, D. M. Kim, S.Y.Kim, S.W.Nam, T.Kim, International Journal of Hydrogen Energy 39, 7925, (2014)

10. T. Kimura, R. Saitou, K. Kubo, K. Nakatsu, H. Ishikawa, K. Sasaki, Hitachi Rev., 63, 96, (2014)

11. M. Zdanowski, J. Rąbkowski, R. Barlik, Energies, 10, 363, (2017) 